\title{
A Review of Corporate Governance: Ownership Structure of Domestic-Owned Banks in Term of Government Connected Ownership, and Foreign Ownership of Commercial Banks in Malaysia
}

\author{
Peong Kwee Kim, Devinaga Rasiah and Rahayu Binti Tasnim \\ Faculty of Business and Law, Multimedia University (Malacca Campus), Malaysia
}

\begin{abstract}
The Asian financial crisis of 1997 resulted in Malaysian commercial banks seeking to strengthen their corporate governance, transparency and disclosure levels. The aim of this research is to review corporate governance in relation to ownership structure of domestic owned banks in terms of government connected ownership and foreign ownership of commercial banks in Malaysia. This research has given a brighter insight into corporate governance and bank performance in selected Malaysian commercial banking institutions. The findings have also provided useful information to investors, bankers and regulators pertaining to the importance of the role of corporate governance practices in the Malaysian banking system and its performance. Different types of bank ownership have had different concerns about implementing corporate governance practices among commercial banks in Malaysia.
\end{abstract}

Keywords: Bank Ownership, Corporate Governance, Banks and Performance.

\section{Introduction}

The Malaysian banking system consists mainly of three types of institutions. There are commercial banks (domestically- owned banks and foreign-owned banks), financial banks and merchant banks. Domestic commercial banks have the largest share of the market. Among these three types of institutions, the government control the largest bank and second largest bank; namely Maybank and Bank Bumiputra through a majority share (Detragiache and Gupta 2004).
According to Bank Negara Malaysia (BNM) (2009), there are presently a total of 55 financial Institutions in Malaysia, comprising 23 commercial banks, 15 investment banks and 17 Islamic banks. The 23 commercial banks include 9 domestic banks and 14 locally- incorporated foreign banks. Foreign commercial banks held over 90 percent of the share of the banking market in 1957 when Malaysia became independent. However, by 1997, they controlled only 16.7 percent of banking assets.

Copyright (C) 2012 Peong Kwee Kim, Devinaga Rasiah and Rahayu Binti Tasnim. This is an open access article distributed under the Creative Commons Attribution License unported 3.0, which permits unrestricted use, distribution, and reproduction in any medium, provided that original work is properly cited. Contact author: Peong Kwee Kim E-mail: kkpeong@mmu.edu.my 
The progressive decline of foreign banks was the result of a deliberate government policy of developing the domestic financial sector, under which foreign banks had been prohibited to open new branches since 1971, and the last licence to a foreign institution was granted in 1973. The market share of foreign banks was relatively stable in the 1990s until the crisis (Detragiache and Gupta 2004).

Domestic and foreign commercial banks had engaged in retail banking and corporate banking. They were the only institutions authorized to take demand deposits. On the other hand, the numerous small finance banks provided instalment credit to consumers and small businesses. Merchant banks were a minor presence at that time. The merchant banks provided short-term money market and capital raising activities including underwriting, loans syndication, corporate finance and management advisory services, arranging for the issue and listing of shares as well as investment portfolio management.

\section{Background Study}

Bank Negara Malaysia's banking sector restructuring efforts was substantially completed. Danamodal was the capital injection vehicle for the central bank. Therefore, the operations of the central bank had been recovered following the closure of the Corporate Debt Restructuring Committee (CDRC). Danaharta also completed its task of acquiring NPLs from the financial sector and was making significant progress in its recovery operations. Danaharta had been very successful in containing the rise of the NPLs in order for the banking system to function efficiently during the intermediation process (Koh 2004).

\section{Ownership Structure of Banks in Malaysia}

Consolidation of the banking industry usually changes the merged banking groups' composition of ownership structure and the banking industry's market structure. In the
Malaysian government's strategy to consolidate the banking industry resulted in the reduction of the number of domestic commercial banks from 20 in 1999 to 10 in 2001 when the bank merger programme was completed (Koh 2004). While the consolidation programme resulted in larger and better capitalised domestic banking institutions, it does not seem to have had any significant effect on the composition of ownership structure in the banking industry. The government's sudden decision to initiate a bank merger programme in 1999 to consolidate the banking industry may have had been prompted by the worsening situation in some of the banking institutions in early 1998. As some banking institutions difficulties became apparent because of their substantial losses and high non-performing loan ratios, the central bank acknowledged that domestic banks were in need of recapitalisation.

The banking regulations on ownership structure are quite effective given that legal ownership was clearly seen in terms of share ownership in the banks. However, discriminating the beneficial ownership structure is more difficult since nominee directors and nominee shareholdings are normal vehicles to cover up the true ownership structure in the banking institutions. The almost status quo position in the ownership and control structure in the banking industry after the merge reflects very much the influence of the government's New Economic Policy (NEP) established in 1970 (Koh 2004). As a result of the New Economic Policy (NEP), restructuring policy, the share of the government ownership in a few of the larger domestic banking groups became substantial with major controlling rights.

There are five main government agencies with large shareholdings in the domestic banking institutions. These five government agencies are Permodalan Nasional Berhad (PNB), the Employees Provident Fund Board (EPF), Khazanah Nasional Berhad, Pertubuhan Keselamatan Sosial (PKS) and 
Kumpulan Wang Amanah Pencen (KWAP). PNB is the government's national capital corporation and Khazanah the Ministry of Finance's investment arm. EPF, PKS and KWAP are the government agencies social security and pension funds (Koh 2004).

There are many studies conducted by other researchers. The past researches have highlighted that the corporate governance and ownership structure impacts bank performance in various perspectives.

\section{Motivation of the Prior Studies}

The recent corporate failures all over the world have reinforced the importance of corporate governance. It is important for investors to differentiate corporate on the basis of governance principles in order to find out the good from the bad. Certainly, corporate governance was the need of the hour. Corporate governance is a control mechanism through which suppliers of finance to corporations assure themselves of getting a return on their investment (Shleifer and Vishney 1997). Corporate governance is concerned with managing the relationship among various corporate stakeholders (Lashgari 2004).

In Malaysia, Tan Sri Dato' Sri Dr. Zeti Akhtar Aziz, the Governor of Bank Negara Malaysia, (2003) said that the corporate governance in banks involves the range of practices covering proper conduct of business, values, ethics and the whole culture of organisational and staff behaviour. It not only involves process and financial targets to serve the interest of the shareholders but also the best practices of conduct with depositors, customers and other stakeholders.

The major contribution of corporate governance was enhancing operating performance of firms and preventing the fraud (Yeh et al. 2002). Black et al. (2002) found that companies with better corporate governance had better financial performance than companies with poor corporate governance. This was well supported by Jensen and Meckling (1976) and Fama and Jensen (1983). They found that corporate governance really helps owners to exert control over corporate affairs. Corporate governance mechanisms have given powerful position to the owners to manage corporate insiders and managers.

\section{Objective}

This study examines the motivation of the prior studies for corporate governance and bank performance. It also presents the structure, evolution and restructuring of the Malaysian banking system. Here, the objectives revolve around three areas:-

1.To look at the literature in relationship between corporate governance and bank performance.

2.Examine literature in relation to the sensitivity of corporate governance on bank performance especially with different types of bank ownerships.

3.Look at the theories relating to the conceptual framework in Corporate Governance.

\section{Literature Review}

\section{Bank Governance and Bank Performance}

In a study conducted by Goodstein et al had indicated that larger boards may act as an increased pool of expertise and a better ability to form reasonable judgment (Goodstein et al. 1994). It is hard to gain an optimum number of directors of the board. Chiang (2005) found insignificant relationship between board structure and firm performance.

Ingrid Bonn (2004) also found that board size never leads to firm performance. He argues that it is not board size, per se, that is important for firm performance but rather the composition of the boards in terms of the ratios of outside directors. Lang et al. (1999) found that inside directors generally had a 
greater understanding of the company's operations. Alonso and Gonzalez (2006) found an inverted U shaped relation between bank performance and board size that justifies a large board and imposes an efficient limit to the board's size. Other than that, Spong and Sullivan (2007) found that boards of directors are likely to have had a more positive effect on community bank performance when directors had a significant financial interest in the bank.

However, outside directors are more professional and in a better position to exert control over management. Fama (1980) stated that independent directors are better in managing and monitoring management of self interest and opportunism. Past researches have shown mixed results on performance influence of outside versus inside directors on firm performance. Most of the researches support outside board members' influence on firm performance. Alonso and Gonzalez (2006) found a positive relation between the proportion of nonexecutive directors' performance and a proactive role in board meetings. They argue that the bank board's composition and functioning are related to director's incentives to monitor and advise management. All these relations hold after they control the bank business, institutional differences, and size and market power in the banking industry, bank ownership and investors' legal protection.

Pearce and Zahra (1984) argued that there was a high degree of association between executive ratio and firm performance. This was well supported by Mahajan and Sharma (1985). They found that a board with high proportion of independent directors works effectively. It was common practice that the CEO of the bank may act as chairman of the board of directors. There was contrasting opinion among researchers regarding the CEO of the firm concurrently acting as chairman of the board. One set of researchers argued against it, just because board effectiveness may come down drastically due to lack of independence. On the other hand,
CEO can give ultimate direction to the boards regarding company's future strategy and bale to run in a proper way. Past researches in the direction provide support for both arguments. Chiang (2005) found it had a negative effect on performance if CEO assumes the role of chairman of the board. The same results were provided by Fama and Jensen (1996). On the other hand, Anderson and Anthony (1986) argue that it may reduce conflict between CEO and the board of directors, and that leads to effective functioning of board. Board meeting is an important element in the board governance.

Apart from that, the literature on the impact of managerial and board ownership structure either inside or outside on performance are also discussed in this research. The effects of the presence of outside directors, especially directors from foreign countries in the corporate board structure have impacts on bank performance. The extent of the foreign ownership level, not the mere existence of foreign ownership, has a significant positive association with the bank return (Choi and Hasan 2005). Choi and Hasan had also indicated that the number of outside board of directors have no significant effect on performance, but the presence of a foreign director on that board is significantly associated with bank return and risk. This was well supported by Dahlquist and Robertsson (2001), who investigated foreign ownership among Swedish firms, and found that foreign investors are typically mutual funds or other institutional investors and reported a positive association with performance.

Bonin et al. (2003) argue that over the second half of the 1990s, foreign ownership in the banking sectors of transition countries increased dramatically. The performance of foreign-owned banks was significantly higher than domestically owned banks, and the extent of such foreign ownership impacted bank efficiency significantly in eleven transition countries. Yudaeva et al. (2003) investigated the effects of foreign ownership on productivity of Russian firms and found 
that foreign firms are more productive than domestic firms. They also found positive spill over from foreign-owned firms to domestic firms in the same industry but reported negative effects on domestic firms that are vertically related to foreign-owned firms. Meanwhile, Havrylchyk (2003) reveals that foreign-owned banks are found to be more efficient than their domestically owned bank counterparts. Goldberg et al. (2000) found that foreign-owned banks outperform domestically owned banks in developing countries.

It is understood that private domestically owned banks have a long term orientation which encourages a strategic approach. Government-connected ownership that controlled private domestic banks seldom give up management control to managers, and they are experts at retaining ownership. Past literature show that governmentconnected ownership was positively significant to profitability. However, it was less significant to market returns. According to Narendar et al. (2005), foreign banks in Indian put up better performance than other domestic banks. The bank controlling rights and cash flow rights have positive correlations in the government-connected ownership of private domestic banks (La Porta et al. 1998). The reason for the wide spread government intervention in private domestic banks in emerging countries is that the government's credibility is more or less dependent on stable financial sectors in the country (Arun and Turner 2002).

The research on the role of the board of directors in Modern Corporation primarily focused on the board's effectiveness in monitoring management (Fama and Jensen 1983). It was argued that by monitoring management, outside directors can limit the exercise of managerial discretion, thus lowering contracting costs between shareholders and management (Fama 1980; Fama and Jensen 1983). Bhagat and Black (2000) found that the proportion of outside directors on the boards is negatively related to firm performance. The quantitative Meta analysis by Rhoades et al. (2000) reports that one third of the variation across board composition studies was the result of sampling error and does not reflect the true differences in the relationship between board composition measure and financial performance.

The research on effect of low ownership concentration on the bank performance, controlling for shareholders protection laws and bank regulations is also discussed here. There exists an interaction with ownership concentration influences on the bank performance in shareholders protection laws. Magalhaes et al. (2008) show the evidence that the increasing ownership concentration is more important to increase bank performance when the protection of shareholders is low. They also argue that ownership concentration is more important to increase the bank performance with concentrated ownership structures when the supervisory authority is less independent from the government and the banking system. This is supported by Pinteris (2002) who provides empirical finding that indicates there was a negative relationship between bank ownership concentration and bank performance.

The following subsection discusses the relationship between corporate governance and bank performance, and the sensitivity of corporate governance and bank performance on the type of bank ownership in detail.

\section{Relationship between Corporate Governance and Bank Performance}

Theoretically, corporate governance is divided into two perspectives which are external governance and internal governance. Both governances have greater impacts on the performance of bank firms. However, the following subsection focuses on the prudential regulations in banking system. Regulations are important for banks because they could discipline all kinds of banking activities of either domestic or foreign commercial banks. 


\section{Prudential Regulations}

As the financial regulatory structure evolved, an umbrella of financial safety nets and prudential regulations was put in place to ensure that the inherent safety and soundness of the banking institutions would promote stability within the financial system. Operationally, this implies that any disruption in the banking system should not have a significant impact on the payments system as well as on aggregate real economic activities. An overriding requirement in developing a viable financial safety net and prudential regulations framework for enhancing effective market discipline is carefully balancing the need for effective regulatory oversight without, at the same time, increasing regulatory burden (Koh 2004).

In banks, depositors rely on the government's role to protect their bank deposits from expropriating management. It might encourage economic agents (bank managers) to deposit their funds into banks because a significant part of the moral hazard cost is guaranteed by the government. In other words, if the government explicitly provides deposit insurance, bank managers probably still have an incentive to increase their risk taking because it is at the government's expense. This moral hazard problem can be restored through the use of economic regulations such as asset restrictions, interest rate ceilings, reserve requirements and separation of commercial banking from insurance and investment banking (Arun and Turner 2003). The effects of these regulations limit the ability of bank managers to over issue liabilities or turn away assets into high risk ventures.

\section{Manager and Director Ownership}

Managers and directors whose personal wealth is significantly linked to the value of the firm have the incentive to act in the interests of outside shareholders. According to Jensen and Meckling (1976), outside shareholders can economically assess the extent to which an owner and manager impose agency costs on other shareholders, the market value of the firm's stock will be reduced, and the owner's wealth will be decreased. Many studies on corporate governance literature cite that increasing stock ownership by managers and directors can be an effective control mechanism designed to reduce the moral hazard behaviour of firm managers. If this was an effective control mechanism, then an increase in the extent of its use would induce a reduction in the level of other monitoring mechanisms such as the presence of block holders and outside directors.

\section{Block Holder Ownership}

The presence of shareholders holding a high proportion of the firm's capital comprises another way to mitigate the effects of the separation of ownership and control on firm value. For example, the manager of a firm in which each shareholder holds only a small fraction of the firm's capital can engage in value reducing activities (Berle and Means 1932). However, in reality, a shareholder with a little stake in the firm have weak incentives to engage in the monitoring of managers since he or she supports all the costs of monitoring, while getting only a small fraction of the benefits or the typical free rider problem (Tam and Tan 2007).

In contrast, an ownership structure in which one or more shareholders own a large block of stock have the potential for disproving managers from engaging in moral hazard behaviour. The presence of block holders may represent a threat to the company's management because of the power to launch a proxy fight, or a takeover bid. A block holder may also propose a person to represent him or her in the board of directors in order to ensure that the management is acting in the interests of shareholders. Consequently, firms with block holder ownership are expected to have less agency problems. 


\section{The Proportion of Outside Directors}

A number of academicians and professionals argue that the presence of directors who are not employees of the firm may enhance the effectiveness of the board of directors in monitoring managers and improving firm value. The rationale behind this statement is that outside directors are more likely to defend the interests of outside shareholders. It can be proven in Fama and Jensen (1983) study that outside directors have the incentive to act as monitors of management because they want to protect their reputations as effective, independent decision makers. On top of that, Weisbach (1988) found that outside dominated boards are more likely than inside-dominated boards to replace the chief executive officer (CEO) in response to poor performance.

\section{Chief Executives Officer (CEO) - Chairman Duality}

Apart from that, many researchers who studied corporate governance consider that separating the titles of chairman and CEO will reduce agency costs and improve firm performance. The reason is that when the CEO is the chairman of the board, the power within the firm becomes concentrated in one person's hands. This allows the CEO to control information available to other board members.

The board becomes under the control of managers, which prevents it from effectively accomplishing its tasks of hiring, ultimately firing, rewarding top executive officers and confirming and monitoring important decisions. Given the decrease in the effectiveness of the board, the potential agency costs resulting from the separation of ownership and decision making are worsening.

Jensen (1993) recommends that companies should separate the titles of CEO and board chairman. Pi and Timme (1993) study a sample of banks over the 1987 to 1990 period. The results of their study suggest that after controlling the bank size and other variables, costs are lower and returns on assets are higher in banks with two different persons holding the $\mathrm{CEO}$ and chairman titles. Control mechanisms are designed to mitigate the agency problem and expected to be used to a larger extent in companies operating with a dual leadership structure.

\section{Board of Directors}

The expenditure defeats the advantages achieved from having more people to depict on. Jensen (1993 p. 865) indicates that by "keeping boards small can help improve their performance. When the number of board of directors gets beyond seven or eight people, they would be lesser probability that they function effectively and difficult for the CEO to control." Lipton and Lorsch (1992) also call for adoption of smaller boards and recommend that board size be limited to seven or eight members.

Yeramck 1996 and Eisenberg et al. (1998) indicate that a number of studies have shown negative results in relation to board size on firm performance. Consequently, corporate mechanisms such as insider block holder ownership and the presence of high proportions of outside directors have developed into an important issue in firms with large boards.

\section{Principal-Agent Problem}

Nonetheless, several markets and governance mechanisms could reduce bank's agency cost. There are several strategies to help reduce agency cost of banking institutions. Firstly, for instance, labour market provides some incentives for bank managers to serve shareholder interests, since better performing managers will be regarded and rewarded more highly and have greater marketability (Fama 1980 and Cannella et al. 1995). Secondly, capital markets can also encourage better performance on the part of bank managers since any performance issues could put pressure on stock prices and increase the 
potential for takeover and new management. Through these market mechanisms, it is a partial substitute for direct incentives for themselves.

\section{The Effect on Bank (Firm) Performance}

Although the classical argument about the relationship between corporate governance variables and firm performance was for some variables, the greater the level of the variable, the better the firm performance, but the opposite holds for other variables; for instance, stock ownership by insider and block holders. The largely shared good sense about these two control mechanisms, the firms with more insider ownership and block holder ownership, is that they achieve a better performance. The same argument holds for the presence of outside directors on the board; for example, the more outside directors the firm have on its board, the better its performance. Regarding the size of the board, a number of researchers and professionals call for smaller boards of directors based on intuition or empirical findings. The rationale behind this is because the effectiveness of larger boards is lower and firms will gain in terms of performance, if they choose to operate with boards composed of a limited number of directors.

\section{Ownership Structure and Bank (Firm) Performance}

In theory, as ownership separates from management, firm performance may decrease due to growing difference in interests between the two persons who are managers and shareholders (Jensen and Meckling 1976). When ownership is concentrated in a single shareholder, there will be closer alignment of interests, and this could affect firm performance. Therefore, conflicts of interest between managers and shareholders are argued to be more important in firms with dispersed ownership structures, as coordination problem hinders effective monitoring of managerial actions by small shareholders, who have to rely on external monitoring through the market for corporate control (Fama and Jesen 1983 and Jensen 1988).

In contrast, conflicts between managers and shareholders are expected to be less important in firms with concentrated ownership structure, as controlling shareholders have strong incentives to monitor managers and replace them in the case of poor performance (Franks et al. 2001).

In summary, monitoring of managerial actions is difficult in a firm with dispersed ownership structure. A concentrated ownership structure providing effective monitoring in principle is expected to enhance firm performance. However, another potential conflict of interest arises in firms with concentrated ownership, as the controlling shareholders may engage in activities that expropriate minority shareholders (Shleifer and Vishny 1986; Faccio and Stolin 2006). Therefore, concentration of ownership may have a negative impact on corporate performance due to expropriation of minority shareholders by controlling shareholders.

In the role of large shareholders model, Burkart et al. (1997) challenge the view that monitoring is simply beneficial by describing a trade off between the benefits of monitoring and the ones of managerial discretion. In other words, too much monitory reduces manager's initiative to seek firm specific investments which is harmful to firm performance. They propose the ownership structure as a commitment device to delegate a certain degree of control to management. The mentioned theories suggest that a non- linear relationship between ownership concentration and firm performance is possible. In fact, Miguel et al. (2004) predicted and found empirical evidence of a quadratic relationship in which performance (firm value) increases at low levels of ownership concentration (due to the monitoring effect), and decreases at high levels (as a result of the expropriation effect). Tam and Tan (2007) show that concentrated 
ownership is positively related to firm performance in Thailand and Asia. Such a relationship was especially pronounced in countries where investor protection was low because ownership concentration was found to mitigate conflicts between owners and managers.

On the other hand, relying on the theoretical argument that expropriation in general is costly (Burkart et al. 1998), we should expect less severe expropriation in a highly concentrated ownership structure. This makes it possible for a cubic relationship between ownership concentration and performance, but until now they are not supported by any empirical evidence (Miguel et al. 2004). Performance or firm value is also argued to increase in the presence of strong shareholder protection laws aimed to avoid expropriation by controlling owners (Classens et al. 2000; La Porta et al. 2002).

The effectiveness of shareholder protection laws is very important in banks because it could affect the relationship between ownership structure and performance. However, the unique characteristics of banks may interfere in such relationship (Caprio et al. 2007). First, due to the higher opacity and complexity of banks (Morgan 2002), investor protection laws alone may not provide effective protection to small shareholders. Second, heavy regulations imposed on banks may substitute for interference with investor protection laws or make these latter extra. As a consequence, it is not clear that we should expect a positive impact of investor protection laws on banks performance and valuation as it is the case for non financial firms. Third, the emergence of bank regulations aimed to reduce expropriation by insiders should enhance bank performance and valuations. Fourth, the presence of deposit insurance aimed to protect depositors through the reduction of excessive risk taking by banks may cause inefficiencies in terms of performance and valuation (Caprio and Levine 2002).

\section{Model Relationship among Ownership Structure, Corporate Governance and Firm Performance}

The subsequently subsection discusses the relationship between corporate governance and bank performance sensitive to types of bank ownership in detail. In general, the type of bank ownership has a greater impact on the performance of banks.

\section{Corporate Governance and Bank Performance: On Types of Bank Ownership}

The type of bank ownership is divided into two categories which are private domestically- owned banks and foreignowned banks. Nevertheless, the structure of bank ownership control can be classified into two groups. They are government-connected ownership for private domestically owned banks and foreign ownership for foreign banks. These structures of bank ownerships have greater significant impacts on corporate governance practices and outcome of bank performance itself. The reason is that the ownership control structure represents the power of owners to control the bank in maintaining their corporate governance.

\section{Government-Connected Ownership}

Government ownership of banks is a common feature in many developing economies (La Porta et al. 2002). The reasons for such ownership may include solving the severe informational problems intrinsic in developing financial systems and aiding the development process (Arun and Turner 2002). The government is more fitted to allocate capital to certain investment (Boubakri et al. 2005).

There are two additional theories which have been advanced for government participation in the financial market, namely the development view and political view. 
The development view suggests that in some countries where the economic institutions are not well developed, government ownership of strategic economic sectors such as banks is needed to jump start both financial and economic development and foster growth. In political view, governments acquire control of banks in order to provide employment and benefit to supporters in return for votes, contributions and bribes. Such approach is greater in countries with underdeveloped financial system and poorly developed property rights. Under development view, government finance projects are socially desirable. Therefore, governments finance projects that would not be privately financed in both views (La Porta et al. 2002).

Greater government ownership of banks tends to be associated with lower bank efficiency, less saving and borrowing, lower productivity and slower growth (Barth et al. 2000). Government residual ownership is likely to have an effect on performance (Boubakri et al. 2005). In Malaysia, the almost status quo position in the ownership and control structure in the banking industry after the merge reflects very much the influence of the government's New Economic Policy (NEP). As a result of the NEP restructuring policy, the share of government ownership in a few of the larger domestic banking groups became substantial with major controlling rights (Koh 2004).

Therefore, most studies have shown that there exist direct relationships between bank performance and government ownership of banks. Government ownership is generally positively related to the level of nonperforming loans in an economy, but not strongly linked to the other performance indicators (Barth et al. 2000).

\section{Foreign Ownership}

With regard to the theme of foreign ownership, prior research suggests that cultural connections might also affect the ability of foreign banks to take full advantage of local opportunities (Clarke et al. 2001). Most sources agree that the more similar the cultural backgrounds of those involved in the interaction process, the greater the likelihood of achieving market closeness (Ford 1989 p.825-826). Cultural likeness is an important determinant of a firm's ability to estimate the needs and requirements of various stakeholders (Holden and Burgess 1994). It may be the mechanism in the interaction process. While trust and experience are only gained or lost through interaction, cultural likeness can be influential before interaction begins (Swift 1999). Head quartered in origin foreign countries versus those located outside the origin countries, Berger et al. (2000) found that foreign-owned banks headquartered in the origin foreign countries are likely to lend to some classes of their small businesses than foreign banks headquartered outside the origin countries. The assumption is that similar culture and language would offer advantages to origin foreign countries rather than from other places. Lark et al. (2001) suggest that any specific advantages foreign banks are likely to have over domestic banks are likely to be greater for foreign banks headquartered within the East Asia region. This is possible due to shorter distances and similarity in language and culture. In fact, the impact of these factors also have been observed in other financial phenomena and used to explain home bias effect of investors who tend to be averse to including foreign stocks in their portfolio (Grinblatt and Keloharju 2001).

\section{Conceptual Framework}

\section{Independent Variables}

Board Ownership Structure

(Internal Governance)

> Government-connected Ownership

> Foreign Ownership

External Forces- Regulation (External Governance) 
$>$ Capital Ratio

Fixed Asset and Inventories to Capital

\section{Dependant Variable}

\section{Bank Performance}

The conceptual framework model shows the relationship between corporate governance and bank performance sensitive to the types of bank ownership in Malaysia. Types of bank ownership moderate the effect of corporate governance on the bank performance in Malaysia. The type of ownership in Malaysia is divided into two perspectives which are foreign-owned banks and second, there are private domestically owned banks. Therefore, these types of bank ownership have a significant effect on internal corporate governance in terms of board ownership structure in banks. This implication may lead to banks having poor or good corporate governance and directly resulting in its profitability increasing or decreasing.

In Malaysia, the ownership structure for private domestically- owned banks consist of government connected ownership, corporate ownership and widely held family and corporate ownership. Nevertheless, in this research, it selects government-connected ownership of private domestically- owned banks in order to have a comparison of corporate governance significant to foreign ownership of foreign-owned banks in Malaysia.

The reason for this is that the government provides a huge amount of funds to bail out savings deposit and takes over temporarily illiquid banks. Banks have a dominant position in developing economic financial systems especially Malaysia and are important engines of Malaysia's economic growth.

Upon review of past studies as discussed earlier, two hypotheses were developed. They are: a) Better corporate governance will lead to better bank performance.

b) The relationship between corporate governance and bank performance is more sensitive for foreign-owned banks rather than for private domesticallyowned banks in Malaysia.

\section{Research Methodology}

The research methodology adopts two exogenous variables in order to align with the goal and objectives in this research as used by KK Peong and D Rasiah (2010). The exogenous variables that are being used in this research constitute capital ratio (CR), and fixed assets and inventories to capital (FAI). Therefore, the ratio of these two exogenous variables is presented as follows:

Firstly the capital ratio is equal to Loan loss provision plus Equity divided by Total loan. Further more the loan loss provisioning was equal to allowance for losses divided by total loan. Secondly the fixed asset and inventories to capital (FAI) is equal to fixed asset and inventories divided capital assets and inventories to capital (FAI). Thirdly fixed asset and inventory is equal to fixed asset and inventory divided by capital.

This study comprised of 4 private domestically- owned banks and 7 foreignowned banks. The following variables were looked at in this study.

- Percentage of shares in shareholders

- Loans and advances

- Total equity

- Loan loss and provision

- Net profit for the year

- $\quad$ Fixed assets

- Share capital 


\section{Proxy Variables for Bank Performance}

This research employs a single proxy for bank performance relevant to return on shareholder's investment, called return on equity (ROE). ROE is a net income available to common stockholders divided by common equity by Brigham and Ehrhardt (2005) and KK Peong and D Rasiah (2010). The ratio of ROE can be shown as Return on equity ( $\mathrm{ROE}$ ) is equal to Earnings divided by common equity.

\section{Regression Model}

This research uses simultaneous equation model. The purpose of using the simultaneous equation model is to examine the causal relationship in higher level of analysis (Bodkin and Hsiao 1996). The coefficient parameters will be estimated by using generalized method of moment (GMM). This technique is useful to eliminate the econometric assumption problem.

Apart from that, this research also adopts the regression model of KK Peong and D Rasiah (2010). As in the earlier discussions, the simultaneous equation model was computed by two exogenous variables of external governance, ownership structure variables for private domestically owned banks and foreign-owned banks (internal governance) and bank performance variable. The simultaneous equation model can be performed in this research as follows:

1) $\mathrm{CAR}_{\mathrm{G}}=\alpha_{1}+\beta_{1} \mathrm{CR}+\beta_{2} \mathrm{FAI}+\beta_{3} \mathrm{OWN}_{\mathrm{G}}+\varepsilon_{1}$

$\mathrm{ROE}_{\mathrm{G}}=\alpha_{1}+\beta_{1} \mathrm{CAR}_{\mathrm{G}}+\varepsilon_{2}$

2) $\mathrm{CAR}_{\mathrm{F}}=\alpha_{1}+\beta_{1} \mathrm{CR}+\beta_{2} \mathrm{FAI}+\beta_{3} \mathrm{OWN}_{\mathrm{F}}+\varepsilon_{1}$

$\mathrm{ROE}_{\mathrm{F}}=\alpha_{1}+\beta_{1} \mathrm{CAR}_{\mathrm{F}}+\varepsilon_{2}$

Descriptions of simultaneous equation model are shown below:

$\mathrm{CR}=$ Capital ratio

FAI $=$ Fixed asset and inventory
$\mathrm{CAR}_{\mathrm{G}}=$ Capital adequacy ratio for private domestically owned banks

$\mathrm{OWN}_{\mathrm{G}}=$ Ownership structure for private domestically owned banks

$\mathrm{ROE}_{\mathrm{G}}=$ Return on equity for private domestically owned banks

$\mathrm{CAR}_{\mathrm{F}}=$ Capital adequacy ratio for foreignowned banks

$\mathrm{OWN}_{\mathrm{F}}=$ Ownership structure for foreignowned banks

$\mathrm{ROE}_{\mathrm{F}}=$ Return on equity for foreign-owned banks

$\alpha=$ intercept

$\beta=$ coefficient of parameters

$\varepsilon=$ residual error

\section{Findings}

The type of bank ownership consists of foreign-owned banks, private domesticallyowned banks and state-owned banks (Berger et al. 2005). Even though Malaysia had stateowned banks in financial institutions, its functions totally differ from commercial banks functions as retail banking. Furthermore, it is also categorised as development financial institution and a nonfinancial institution. Thus, only two types of bank ownership are investigated in this research, which are foreign-owned banks and private domestically- owned banks.

In internal governance mechanisms, ownership structure has an important role as a key determinant of corporate governance. This variable represents controlling shareholders who govern the policy of the firm in implementing good corporate governance (Supriyatna et al. 2007). Ownership structure is the relative amount of ownership claims held by insiders (management) and outsiders (investors with no direct role in the management of the firm) 
(Jensen and Meckling 1976). The highest proportion percentage of ownership structure (majority ownership) indicates the higher power of the owners to control the bank. In this research, the measurement of ownership structure is based on the highest proportion percentage of governmentconnected ownership $\left(\mathrm{OWN}_{\mathrm{G}}\right)$ for private domestically- owned banks. This research also measures the highest proportion percentage of foreign ownership $\left(\mathrm{OWN}_{\mathrm{F}}\right)$ for foreign-owned banks in Malaysia perspective. The $\mathrm{OWN}_{\mathrm{G}}$ and $\mathrm{OWN}_{\mathrm{F}}$ represent the power of owners to control the bank in maintaining their corporate governance.

\section{Discussion and Conclusion}

In brief, there have been multiple bank closures and substantial overhaul of banking regulation among Malaysian banks especially private domestically- owned banks and foreign-owned banks. Banks are to make changes in order to be globally standard and to be able to compete for stability and profitability of the banking sector. There has been no study in the literatures examining the effects of corporate governance in private domestically-owned banks and foreignowned banks on bank performance respectively. This study employs foreign and domestic commercial bank data from 1995 to 2005 to investigate the effect of corporate governance and bank performance, mainly transparent ownership and governance on bank performance of private domesticallyowned banks and foreign-owned banks in Malaysia. Particularly, this research investigates foreign ownership as well as capital and fixed assets and inventory to capital on the return or bank performance of sample foreign banks.

Empirical studies indicate that managers ought to be concerned about possession, and that good governance effects on good bank performance and profitability. In Malaysia, the researchers have identified that there are two types of bank ownership which are private owned banks and the domesticallyowned banks or foreign-owned banks. These findings confirm that foreign-owned banks were implementing good corporate governance and had higher advantage of increasing their performance, and private domestically- owned banks were at implementing corporate governance. As a result, they have a better performance than that of foreign-owned banks. Subsequently, shareholders with information also have an important role to pay and they can force the bank management to implement better corporate governance. In order to be positive, bank managers implement efficient corporate governance and establish positive control mechanism. This may have different concerns on implementing good corporate governance. For example, foreign-owned banks may be concerned about implementing good corporate governance practices across various management levels. As a result, their performance is much better than that of private domestically- owned banks in the Malaysian banks.

Bank Negara Malaysia or the Central Bank of Malaysia has to encourage commercial banks to implement corporate governance practices through enacting rules and regulations. Good Corporate governance practices in commercial banks will be positive that banks maintain the level of risk they can handle and give depositors a sufficiently safe level of their savings and investments. Several commercial bank regulations encourage good corporate governance practices and as such have implemented lending limits, the quality of assets, knowledge of your customers and regulations against money laundering as indicated by Bank Negara Malaysia Regulation Guidelines (From BNM/GP1 till $\mathrm{BNM}$ / GP11). As a result, privately- owned and domestically- owned banks in Malaysia have a good performance because of implementing superior corporate governance.

\section{References}

Adams, R. \& Mehran, H. 2002. 'Board Structure and Banking Firm Performance,' 
Working Paper, Federal Reserve Bank of New York.

Aebi, V., Sabato, G. \& Schmid, M. (2011)."Risk Management, Corporate Governance and Bank Performance in the Financial Crisis," $10^{\text {th }}$ Guberna European Corporate Governance Conference. Brussels.

Allen, F., Gu, X. \& Kowalewski, O. (2011). "Corporate Governance and Intra-group Transactions in European Bank Holding Companies During the Crisis," Ed. [ Online]. [Retrieved February 20, 2011]. http:/ / fic.wharton.upenn.edu/ fic/ papers/ 11 /11-35.pdf

Alonso, Pablo de Andres \& Gonzalez, Eleuterio Vallelado. (2006)."Corporate Governance in Banking: The Role of Board of Directors," Documents de treball d'economia de l'empresa Series, Department of Financial Economics and Accounting, University of Valladolid.

Anderson \& Anthony. (1986). The Corporate Director, New York: Wiley Publication.

Arun, T. G. \& Turner, J. D. (2002). "Financial Sector Reform in Developing Countries: The Indian Experience," The World Economy. 25(3): 429-445.

Arun, T. G. \& Turner, J. D. (2002). "Public Sector Banks in India: Rationale and Perquisites for Reform," Annals of Public and Corporate Environment. 1: 73.

Arun, T. G. \& Turner, J. D. 2003."Corporate Governance of Banks in Developing Economies: Concepts and Issues,"

Banking and Financial Institutions Act (1989). (Malaysia) (ACT 372).

Barth, J. R., Caprio, G. \& Levine, R. (2000). Banking Systems Around the Globe: Do Regulation and Ownership Affect Performance and Stability?. National Bureau of Economic Research.

Berger, A. N., Clarke, G. R. G., Cull, R., Klapper, L. \& Udell, G. F. (2005). "Corporate
Governance and Bank Performance: A Joint Analysis of the Static, Selection, and Dynamic Effects of Domestic, Foreign, and State Ownership," Working Bank Policy Research Working Paper 3632. Washington. D.C.

Berger, A. N., DeYoung, R., Genay, H. \& Udell, G. F. (2000)."Globalization of Financial Institutions: Evidence from Cross-Border Banking Performance,"Brookings Papers on Economic Activity. 2: 23-158.

Berger, A. N., Klapper, L. F. \& Udell, G. F. (2000). 'The Ability of Banks to Lend to Informationally Opaque Small Businesses,' Mimeo. World Bank: Washington DC.

Berle, A. A. \& Means, G. C. (1932). 'The Modern Corporation and Private Property,' New York: Commerce Clearing House.

Bhagat, S. \& B. Black. (2000)."Board independence and long term firm performance,"Working paper. Colombia Law School.

Black, Jang \& Kim. (2002). 'Does Corporate Governance Affect Firm Value? Evidence from Korea,' Working Paper No. 237. Stanford Law School.

Bonin, J. P., Hasan, I. \& Wachtel, P. (2003). "Bank Performance, Efficiency, and ownership in Transition Countries," Journal of Banking and Finance. 29(1): 31-53.

Boubakri, N., Cosset, J.- C. \& Fisher, K. (2005). 'Ownership Structure, Privatization, Bank Performance and Risk Taking,' Journal of Banking and Finance. 29: 2015-2041.

Brewer III, E., Jackson III, W. E. \& Jagtiani, J. (2000). "Impact of Independent Directors and the Regulatory Environment on Bank Merger Prices: Evidence from Takeover Activity in the 1990s," Working Paper 200031. Federal Reserve Bank of Chicago.

Brigham, Eugene F. \& Ehrhardt, Michael C. (2005). 'Financial Management: Theory and 
Practice 11th Ed,' United States of America: South-Western, Thomson Corporation.

Burkart, M., Gromb, K. \& Panunzi, F. (1997). 'Large Shareholders, Monitoring, and Fiduciary Duty,' Quarterly Journal of Economics. 112: 693-728.

Burkart, M., Gromb, K. \& Panunzi, F. (1998)."Why Higher Takeover Premia Protect Minority Shareholders," Journal of Political Economy. 106: 172-204.

Cannela, A. A., Fraser, D. R. \& Lee, D. S. (1995). "Firm Failure and Managerial Labour Markets: Evidence from Texas Banking," Journal of Financial Economics. 38: 185-210.

Caprio, G., Laeven, L. \& Levine, R. (2007). "Governance and Bank Valuation," Journal of Financial Intermediation, Forthcoming.

Caprio, G. \& Levine, R. (2002). "Corporate Governance in Finance: Concepts and International Observations," Washington, DC: Brookings Institution Press.

Chiang, Hsiang-Tsai. (2005). "An Empirical Study of Corporate Governance and Corporate Performance,"The Journal of American Academy of Business.March:95-101.

Choi, S. \& Hasan, I. (2005). "Ownership, Governance, and Bank Performance: Korean Experience," Financial Markets, Institutions and Instruments. 14(4). New York: Blackwell Publishing Inc.

Christopher, M. F. Y. (2009). "The Relationship between Corporate Governance and Bank Performance in Hong Kong," Ed. [Online]. [Retrieved December 10, 2010]. http:/ / aut.researchgateway.ac.nz/ bitstream/ 10292/ 739/ 4/YungMF.pdf

Ciancanelli, P. \& Gonzalez, J. A. R. (2000). "Corporate Governance in Banking: a Conceptual Framework," Social Science Research Network. Electronic Paper Collection: http:/ / papers.ssrn.com/ paper.taf?abstract_id $=253714$. [17 January 2008].

Claessens, Stijn, Asli, Demirguc-Kunt \& Harry, Huizinga. (2001). "How Does Foreign Entry Affect the Domestic Banking Market?," Journal of Banking and Finance. 25(5): 891911.

Claessens, S., Djankov, S. \& Lang, L. H. P. (2000). "The Separation of Ownership and Control in East Asian Corporations," Journal of Financial Economics. 58: 81-112.

Claessens, Stijn \& Fan, Joseh P. H. (2003). 'Corporate Governance in Asia: A Survey,' Working Paper. Finance Group. University of Amsterdam. Roetersstraat Amsterdam.

Clarke, G., Cull, R., Martinez Peria, M.S. \& Sánchez, S.M. (2001). 'Bank Lending to Small Businesses in Latin America: Does Bank Origin Matter?,' Mimeo. World Bank: Washington $D C$.

Dahlquist, M. \& Robertsson, G. (2001). "Direct foreign ownership, institutional investors, and firm characteristics," Journal of Financial Economics. 59: 413-440.

Detragiache, Enrica \& Gupta, Poonam. (2004). Foreign Banks in Emerging Market Crises: Evidence from Malaysia. IMF Working Paper. International Monetary Fund.

De Miguel, A., Pindado, J. \& de la Torre, C. (2004)."Ownership Structure and Firm Value: New Evidence from Spain," Strategic Management Journal. 25: 1119-1207.

Douma, Sytse, Rejie George \& Rezaul Kabir. (2003). "Foreign and Domestic Ownership, Business Groups and Firm Performance: Evidence from Large Emerging Market," Working Paper. Tilburg University.

Eisenberg, T., Sundgren, S. \& Wells, M. T. (1998). "Larger Board Size and Decreasing Firm Value in Small Firms," Journal of Financial Economics. 48: 35-54 
Fama, E. F. (1980). "Agency Problem and the Theory of the Firm," Journal of Political Economy. 88(2): 288-307.

Faccio, M. \& Stolin, D. (2006). "Expropriation vs. Proportional Sharing in Corporate Acquisitions," Journal of Business. 79(3): 1413-44.

Fama, E. F. \& Jensen, M. C. (1983). "Separation of Ownership and Control," Journal of Law and Economics. 26: 301-325.

Ford, D. (1989). 'One More Time: What Buyer-Seller Relationships are All About,' Research in Marketing: An International Perspective. Penn State University Press. OH. 813-36.

Franks, J., Mayer, C. \& Renneboog, L. (2001). "Who Disciplines Management in Poorly Performing Companies?," Journal of Financial Intermediation. 10: 209-248.

Grinblatt, M. \& Keloharju, M. (2001). "How Distance, Language and Culture Influence Stockholding and Trades," The Journal of Finance. 56(3):1053-1074.

Hasan, I. \& Marton, K. (2003). 'Banking In Transition Economy: Hungarian Evidence,' World Bank Conference on Bank Privatisation. Nov: 20-21.

Holden, N. \& Burgess, M. (1994). Japaneseled Companies: Understanding How to Make Them Your Customers, London: McGraw-Hill Book Company

Havrylchyk, Olena. (2003). 'Efficiency of the Polish Banking Industry: Foreign Versus National Banks,' Working Paper. Department of Economics. European University Viadrina Frankfurt.

Ingrid Bonn. (2004). "Board Structure and Firm Performance: Evidence from Australia," Journal of the Australian and New Zealand Academy of Management. 10: 14-24.
Jensen, M. C. (1993). "The Modern Industrial Revolution, Exit, and Failure of Internal Control Systems," The Journal of Finance. 48: 831-880.

Jensen, M. C. \& Meckling, W. H. (1976). "Theory of the Firm: Managerial Behaviour, Agency Cost, and Ownership Structure," Journal of financial Economics. 3: 305-360.

Jeon, Yongil \& Miller, Stephen M. (2006). "Market Definition, Concentration and Bank Performance," Working Paper. Las Vegas: University of Nevada.

Jerry Goodstein, Kanak Gautam \& Warren Boeker (1994). "The Effects of Board Size and Diversity on Strategic Change," Strategic Management Journal. 15: 241-250.

Koh, P. T. N. (2001). '3R's of Corporate Governance: Responsibilities, Risks and Reform,' Kuala Lumpur: Printmate Sdn. Bhd.

Lange, H., Ramsay, I. \& Woo, L.- A. (2000). "Corporate Governance and Anti-Takeover Devices: Evidence from Australia," Corporate Governance. An International Review. 8(3): 227-243.

Larry H.P. Lang, René M. Stulz \& Ralph A. Walkling (1989). "Managerial Performance, Tobin's Q, and the Gains from Successful Tender Offers," Journal of Financial Economics. 24(1): 137-154.

Lashgari, Malek, CFA (2004). "Corporate Governance: Theory and Practice," Journal of American Academy of Business. 5: $46-51$.

Llewellyn, David \& Sinha, Rajeeva. (2000). 'Monitoring and Control of Banks: The Role of Regulation and Corporate Governance,' Working Paper. Department of Economics: Loughborough University.

Linda Goldberg, B. Gerard Dages \& Daniel Kinney (2000). "Foreign and Domestic Bank Participation in Emerging Markets: Lessons From Mexico and Argentina," Working Paper 
$7714 . \quad$ May. Online: http:/ / www.nber.org/ papers/ w7714.

[25 February 2008].

Lipton, M. \& Lorsch, J. W. (1992). "A Modest Proposal for Improved Corporate Governance," Business Lawyer. 48: 59-77.

Lopez-de-Silanes, F., La Porta, R., Shleifer, A. \& Vishny, R. (2002). "Investor Protection and Corporate Valuation," Journal of Finance. 57(3): 1147-1170.

Low, K. L. T. (2003). 'Perspectives on Corporate Governance and Management,' 2. Kuala Lumpur: Percetakan Cergas (M) Sdn. Bhd.

Lum Chee Soon \& Koh, P. T. N. . (2004). "Corporate Governance of Banks in Malaysia," Working Paper. Online: http:/ / www.ibbm.org.my/pdf/ KRBJM003\%2 0Philip.pdf. [5 March 2008].

Magahaes, R., Gutierrez, M. \& Tribo, J. A. (2008). "Bank's Ownership Structure, Risk and Performance," Working Paper. Department of Business Administration: Universidad Carlos III de Madrid.

Malkonen, Ville. (2004). Capital Adequacy Regulation and Financial Conglomerates. Bank of Finland Discussion Papers 10/ 2004. Research Department.

Melvin, Colin, \& Hirt, Hans. (2005). 'Corporate Governance and Performance: A Brief Review and Assessment of the Evidence for a Link between Corporate Governance and Performance,' London: Hermes Pensions Management Ltd.

rhttp:/ / papers.ssrn.com/ paper.taf?abstract i d=253714http:// papers.ssrn.com/ paper.taf? abstract_id=253714

Michael, D. I., Bodkin, R. G. \& Hsiao, C. (1996). Econometric Models, Techniques, and Applications. USA: Prentice Hall International.
Morgan, D. P. (2002)."Rating banks: Risk and uncertainty in an opaque industry," American Economic Review. 92: 874-888.

Morgan, D. P. \& Strahan, P. E. (2003). "Foreign Bank Entry and Business Volatility: Evidence from U.S. States and Other Countries," NBER Working Paper No. 9710. Cambridge, Massachusetts: National Bureau of Economic Research.

Narendar, Rasoul \& Emmanuel (2005). 'Profitability of Banks in India: An Assessment and Alliance,' Journal of Business Research.68-89.

Online:http:/ / www.mida.gov.my/ beta/ view. php?cat=3\&scat=30\&pg=157. $\quad[20$ March 2008].

Online: http:// en.wikipedia.org. [17 March 2008].

Peong Kwee Kim \& Devinaga Rasiah (2010). "Relationship between Corporate Governance and Bank Performance in Malaysia during the Pre and Post Asian Financial Crisis," European Journal of Economics, Finance and Administrative Sciences. ISSN 1450-2275 Issue 21 (2010)

Pi, L. \& Timme, S. G. (1993). "Corporate Control and Bank Efficiency," Journal of Banking and Finance. 17: 515-530.

Pinteris, G. (2002. 'Agency Costs, Ownership Structure and Performance in Argentine Banking,' Working Paper. Department of Economics. Urbana: University of Illinois.

Radelet, S. \& Sachs, J. (1998). "The East Asian Financial Crisis: Diagnosis, Remedies, Prospects," Brookings Papers on Economic Activity. 1:1-74.

Rafael La Porta, Florencio Lopez-de-Silanes, Andrei Shleifer \& Robert W. Vishny. (1998). "Law and Finance," Journal of Political Economy. 106: 1113-1155.

Rafel $\square$ Crespía, $\square$ Miguel $\square$ A. $\square$ García-Cestonab \& Vicente Salas (2004). "Governance 
Mechanisms in Spanish Banks. Does Ownership Matter?," Journal of Banking and Finance. 2311-2330.

Rajeswararao S. Chaganti, Vijay Mahajan \& Subhash Sharma (1985). "Corporate Board Size, Composition and Corporate Failures in Retailing Industry," Journal of Management Studies. 22: 400-417.

Rhoades, D. L., Rechner, P. L. \& Sundaramurthy, C. (2000)."Board Composition and Financial Performance: A Meta-Analysis of the Influence of Outside Directors," Journal of Managerial Issues. 12:76-92.

Ruin, Josef Eby (2001). 'Essentials of Corporate Management,' Kuala Lumpur: Malaysian Institute of Corporate Governance (MICG).

Sauve, Pierre (2006). 'Fostering Trade through Private-Public Dialogue: WTO Negotiations on Trade in Services Commercial and Economic Implications,' Working Papers. Washington. D.C.

Shaker A. Zahra \& John A. Pearce II (1984). "Boards of Directors and Corporate Financial Performance: A Review and Integrative Model," Journal of Management. 15: 291-334. Shleifer, A. \& Vishny, R. W. (1997). "A Survy of Corporate Governance," Journal of Finance. 52: 737-783.

Spong, K. \& Sullivan, R. J. (2007). "Corporate Governance and Bank Performance," Research Department: Federal Reserve Bank of Kansas City.

Tandelilin, E., Kaaro, H., Mahadwartha, P. A. \& Supriyatna (2007). "Corporate Governance, Risk Management and Bank Performance: Does Types of Ownership Matter?," EADN Working Paper No. 34. Indonesia.

Thomas, T. (2002). "Corporate Governance and Debt in the Malaysian Financial Crisis of 1997-98," Working Paper Series. UK: Centre Secretary.
Weisbach, M. S. (1988). "Outside Directors and CEO Turnover," Journal of Financial Economics. 20: 431-460.

Wheelen, Thomas L. \& Hunger, J. David. (2006). Strategic Management and Business Policy. 10 ${ }^{\text {th }}$ Ed. United States of America: Pearson Prentice Hall.

World Bank. (1998). East Asia: The Road to Recovery. Oxford, UK: Oxford University Press.

World Bank. (2002). Global Development Finance. Washington. D.C.

Yeh, Lee \& Ko. (2002). 'Corporate Governance and Rating System,' Journal of Financial Economics.

Yermack, D. (1996). "Higher Market Valuation of Companies with a Small Board of Directors," Journal of Financial Economics. 40: 185-211.

Yudaeva, K., Kozlov, K., Melentieva, N. \& Ponomareva, N. (2003). "Does Foreign Ownership Matter?: The Russian Experience," Economics of Transition. 11: 383-409.

Zeti Akhtar Aziz. (2003). "Corporate Governance: Towards Preserving Financial Stability and Sustainable Growth," Bank Negara Malaysia, Online: http:// www.bnm.gov.my/ files/ publication/ a r/ bm/ 2003/ cp04.pdf. [15 March 2008].

Zikmund, William G. (2003). Business Research Methods. $7^{\text {th }}$ Ed. United States of America: Thomson South-Western.

Zingales, L. (1994). "The Value of the Voting Right: a Study of the Milan Stock Exchange Experience," Review of Financial Economics. 7: 125-148.

Zubaidah Zainal Abidin (2004). 'Malaysian Company Secretarial Practice,' Selangor: Pearson Malaysia Sdn. Bhd. 